\title{
BENTUK PERLAWANAN PETANI DENGAN DIBANGUNNYA KAMPUS UNIVERSITAS MULIA DI PROPINSI DAERAH ISTIMEWA YOGYAKARTA
}

\author{
Oleh: Djaja Hendra*
}

\begin{abstract}
The contruction of the campus mulia in the D.I Yogyakarta region is one among the existing development. The contruction of the campus mulia is done in the suburbs, with the hope of being the "trigger" of the blossoming of the city. Apart from that, the construction of the campus mulia, seems to be different from that depicted by Scott (1983). The forms of peasant resistance in Southeast Asia, especially Burma and Vietnam are not as described. Althought Indonesia entered Southeast Asia as well but the forms of resistance peasents are not like their cooleagues. Perhaps past political trauma also colored; so as not to take forms of direct resistance but perhaps indirect forms of resistance. They do get compensation that they realize in various ways but most importantly that they are very accommodating; while the rest (accommodative) some move to sub-districts or other areas or change professions and fear of being labeled as persons entering forbidden parties (past political trauma).
\end{abstract}

Keywords: Peasants, resistance, campus.

\begin{abstract}
ABSTRAK
Pendirian kampus Universitas Mulia di Propinsi Daerah Istimewa Yogyakarta adalah bagian dari kewujudan pembangunan. Kampus tersebut didirikan di kawasan sub urban dengan harapan akan memicu pertumbuhan ekonomi wilayah kota. Selain itu, pembangunan kampus universitas tersebut nampaknya berbeda dari apa yang digambarkan oleh James Scott (1983) tentang perlawanan petani terhadap penguasa. Bentuk-bentuk perlawanan petani di kawasan Asia Tenggara, khususnya Burma dan Vietnam tidaklah sesuai dengan kenyataan yang ada di Yogyakarta. Meskipun Indonesia merupakan bagian dari Asia Tenggara, tetapi bentuk-bentuk perlawanan petani yang muncul tidaklah seperti di negara-negara se kawasan tersebut. Barangkali trauma politik pada masa lalu ikut mempengaruhi, sehingga para petani tidak mengambil bentuk perlawanan yang bersifat langsung tetapi bersifat tidak langsung. Mereka menyadari adanya resiko yang harus dibayar, sehingga sangat akomodatif terhadap kenyataan yang ada. Sementara sebagian anggota masyarakat yang lain yang tidak berani menentang pembangunan universitas tersebut pindah ke kecamatan atau daerah lain atau mengubah profesi mereka, karena takut dicap sebagai anggota partai politik terlarang (PKI).
\end{abstract}

\footnotetext{
*Dosen pada Universitas Widya Mataram Yogyakarta. Email:djajahendra@g.mail
} 
Kata Kunci: Petani, perlawanan, kampus.

\section{Pendahuluan}

Sudah lebih dari 35 tahun kampus mulia itu berdiri di wilayah D.I. Yogyakarta, belum ada tanda-tanda segala bentuk perlawanan petani sebagaimana yang digambarkan Scott (1983), atau mungkin tidak sekualitas Scott, kecuali tulisan yang dibuat oleh Kartodirdjo atas disertasinya berjudul: "Pemberontak Petani Banten 1888" (1984) atau gejala "Radikalisme Petani” di Madura (Kuntowijoyo, 1993) dan seterusnya; atau sosiolog-sosiolog lainnya di Indonesia masih meneliti yang kecil-kecil. Seperti yang dilukiskan Scott bahwa petani akan melakukan perlawanan dan mungkin pemberontakan terhadap siapapun (termasuk pemerintah) jika pungutan tentang pajak, yang biasanya besar, dilakukan penarikannya secara tidak teratur (ajeg). Katakanlah, bulan yang sedang berjalan, ditarik besaran pajak tertentu dan dilakukan penarikan ulang 6 bulan kemudian. Dipastikan petani akan melakukan perlawanan berbentuk pemberontakan sebagaimana kajiannya terhadap petani di Asia Tenggara terutama Vietnam dan Burma.
Demikianlah, sosiolog lain pun mengatakan hal yang hampir sama, bahwa petani akan merubah sikap dan perilaku dengan adanya kampus baru di wilayah mereka. Sikap dan perilaku tersebut seirama dengan kemampuan ekonomi dan status sosial mereka. Artinya, mereka akan melakukan adaptasi sosial terhadap segala bentuk intervensi yang datang dari luar terhadap mereka bila status ekonomi dan sosial mereka tidak memadai misalnya. Lantas mereka akan membentuk adaptasi sosial, katakanlah, mereka akan membangun warung-warung makan, laundry, tokotoko kelontong, warung telekomunikasi, jasa penerjemah, foto copy, satuan pengamanan (satpam), cleaning service, jasa asisten rumah tangga, tempat penitipan anak (TPA), jasa kos dan lain sebagainya; atau bagi mereka yang cukup mampu kemudian menjual tanah dan rumah tinggal mereka kepada orang asing (tentu dengan harga layak saat itu) atau mereka yang masih tetap bertahan sebagai petani di wilayah mereka tetapi harus sanggup, menghadapi gempuran dari luar, atau dengan membeli tanah dan rumah tinggal kembali (mereka adalah 
petani) di lain tempat baik di kecamatan yang sama atau di daerah lain.

Sepuluh tahun kemudian, Scott (1993) kembali melakukan penelitian yang dituangkan dalam sebuah buku dengan judul: Perlawanan Kaum Tani dan diberi pengantar oleh Sayogyo. Mungkin masalah yang diangkat agak berbeda dan nampaknya Scott memperluas kajiannya. Scott mengkaji di Burma, Viet Minh, Hukbalahap dan Madiun-Indonesia terutama pemberontakan komunis Bendera Merah dan Putih pada masa PD II. Dengan berlandaskan agraria tetapi yang disoroti tentang erosi patron-klien di semua desa yang dikaji. Asumsi yang dibangun Scott, pertama, hubungan antara petani dan elit agraria dapat diibaratkan sebagai hubungan pertukaran yang vertikal, di mana perubahan-perubahan dalam legitimasi kaum elit - secara kolektif maupun individual - berhubungan langsung baik dengan perubahan dalam neraca peralihan barang dan jasa - nilainilai perdagangan - di antara mereka maupun dalam sifat kelengkapan pertukaran tersebut.

Walaupun neraca pertukaran tidak dapat dikuantitatifkan sejauh melibatkan barang dan jasa yang tidak setara serta beberapa jasa yang terlalu kecil seperti pertahanan, namun umumnya memungkinkan untuk menentukan dalam suatu waktu tertentu ke arah mana neraca pertukaran bergerak dan untuk membedakan perpindahan marginal dari perpindahan utama. Kedua, legitimasi patron bukanlah hanya fungsi linier dari neraca pertukaran; terdapat beberapa ambang batas atau "titik-titik menonjol" dalam neraca tersebut, yang menimbulkan perubahan-perubahan tajam.dari kelas patron dan memberikan basis moral bagi kaum tani untuk tindakan melawan elit agraria. Ketiga, secara keseluruhan....dipengaruhi oleh perubahan-perubahan struktural seperti kelangkaan lahan, perubahan ke pertanian kemersial, ekspansi kekuasaan negara dan pertumbuhan penduduk. Keempat, ciri-ciri struktural tertentu dari Asia Tenggara....berfungsi menyediakan jaminan minimum bagi klien petani. Kelima, perubahan politik dan ekonomi pada pemerintahan kolonil secara sistematis melemahkan sifat komprehensif atau kelengkapan dari pertukaran....Keenam, stratifikasi pedesaan makin terpolarisasi antara produsen bebas dan terikat, sementara neraca pertukaran beralih lebih jauh ke arah yang merugikan peteni.... 
Dari dua penelitian yang dilakukan Scott, nampak telah ada pergeseran-pergeseran dari yang semula dan masih berbasis agraria ke yang lebih kompehensif termasuk petron-klien. Semua yang dilakukan masih berkaitan dengan Asia Tenggara. Hanya bedanya peran pemerintah dimasukan sebagai variabel tersendiri dan pengganggu di antara variabel-variabel lain dalam kajiannya yang kedua itu. Tetapi basis agraria tetap diperlukan dalam memaknai petani serta variabel yang menyertainya. Karena agak sulit saya kira mengulas sesuatu tanpa menyertakan petani pedesaan di Asia Tenggara. Sebagai negara agraris fokus utama setiap kajian memang petani. Di luar itu, untuk sekarang ini, memang sudah bisa dilakukan tetapi masih sangat terbatas. Kecuali negara itu sudah berubah posisinya yakni tidak lagi sebagai negara agraris tetapi sudah berubah sebagai negara industri misalnya. Dalam suatu statistik negara ditunjukkan masih lebih dari $50 \%$ rakyat bergerak di dalam sektor tertentu maka negara tersebut sudah dianggap sebagai negara apa, misalnya pertanian, berburu dan meramu atau negara industri sekalipun.

Pendapat Lenner tahun 1950 dalam banyak hal mungkin ada benarnya pula. Dalam hal ini, siapa yang tidak mengenal dan mengetahui seorang tokoh kepala desa; berbagai kebijakan yang dilakukan pemerintah tentu harus diketahui termasuk hajatan desa; demikian pula dengan seorang pedagang, siapa yang tidak mengenalnya. Hampir semua penduduk di desa Balgat $8 \mathrm{~km}$ selatan Ankara Turki mengenal dengan baik, di mana dia selalu datang-pergi di desa mereka. Orang dapat berhutang dan mengangsur, tentu saja atau ada yang membayar kontan terhadap dagangannya; tetapi tidak demikian halnya dengan seorang pengembala kambing, sementara dia hanya bermukim di desa saja tidak pernah pergi ke manamana sehingga dia adalah orang yang paling sedikit mengalami perubahan dan perubahan-perubahan yang terjadi selalu dibicarakan terlebih dahulu kepada anakanak dan istri serta kerabatnya. Paling tidak, itu yang tergambar dalam benak Lenner setelah 4 tahun berikutnya. Tetapi apa yang kemudian terjadi? Lenner melihat memang banyak terjadi perubahan di desa yang pernah dikunjungi tersebut, bahkan dia sendiri hampir tidak mengenal desa tersebut sama sekali saking banyaknya perubahan-perubahan. 
Beliau menemui kembali orangorang yang pernah mengenalnya. Dari cerita yang dikemukakan Lenner, ternyata pedagang yang paling banyak berubah, menyusul kepala desa dan yang terakhir adalah pengembala-kambing. Berbagai isu-isu dengan sangat mudah didapat sang pedagang bahkan anak si pedagang pun bersekolah di kota lain. Menyusul, seorang kepala desa mungkin banyak berubah tetapi perubahanperubahan seputar peraturan-peraturan desa yang diberikan oleh pemerintah daerah kepada dirinya sebagai perpanjangan tangan pemerintah maupun hajatan-hajatan desa. Sedangkan, yang paling sedikit mengalami perubahan adalah pengembala-kambing yang hanya berbicara tentang kambing-kambingnya dan desanya belaka kepada anak-istri dan kerabatnya (Lenner, 1983).

Apa yang dapat disimpulkan dari cerita di atas, yakni adanya perubahanperubahan sosial mengikuti zamannya dalam diri seseorang. Perubahanperubahan sosial ada yang sangat cepat dan ada yang sangat lambat, tergantung dari hubungan-hubungan sosial seorang aktor yang terbentuk dan tersosialisasikan. Pengembala-kambing adalah orang yang paling lambat melakukan perubahan, pasalnya mobilitas sosialnya hanya seputar desanya anak-istri dan kerabat belaka. Sehingga mudah ditebak bahwa ceritanya hanya yang itu-itu saja. Berbeda dengan pedagang, karena dia menelusuri desa dan kota lain dalam menjajakan barang dagangan; sehingga isu-isu dan perkembangan apapun yang terjadi di suatu desa atau kota, hampir dipastikan dia mengetahui; juga dirinya harus bersikap ramah dan murah senyum kepada orang lain yang ditemui.

Deskripsi demikian, sama dengan perubahan-perubahan sosial yang terjadi di suatu wilayah di D.I Yogyakarta, atas pendirian kampus mulia. Observasi dilakukan sejak tahun 90-an hingga sekarang ini pasti terjadi perubahan. Di sini, kita melihat bentuk-bentuk perubahan atau transformasi sosial maupun bentuk-bentuk perlawanan petani di wilayah itu? Kampus mulia, konon katanya milik pemerintah, yang sedianya sebagai pemicu mekarnya kota. mungkinkah dapat terjadi? Itulah sebabnya dia dibangun di pinggiran kota dan disediakan berbagai fasilitas pendukung lainnya; atau mungkin asal membangun saja tanpa pertimbanganpertimbangan tertentu misalnya takut anggaran tidak bisa diserap sehingga pusat (Jakarta) tidak lagi menganggarkan 
tahun berikutnya; atau kampus mulia merupakan kampus yang berbeda dengan kampus lainnya dan lain-lain. Untuk itu tidak terlalu dipersoalkan, tetapi hubungan dengan pemicu mekarnya kota dengan daya dukungnya seperti agraria misalnya, hingga sekarang belum kelihatan buktinya. Kampus lain tetapi baru sama sekali juga tidak terbangun.

\section{Pendirian Kampus Mulia Di} Yogyakarta.

Pendirian kampus mulia (juga atas bantuan negara lain), akan terbangun pula pada pendirian kampus-kampus baru lain di Daerah Istimewa Yogyakarta terutama di sekitar kampus mulia yang telah berdiri dengan segala program studinya itu. Para sosiolog ingin mengatakan bahwa cara demikian sebagai isu pada pemicu mekarnya kota dengan berbagai fasilitas, ternyata belum lagi muncul. Dengan dibangun satu kampus maka akan dengan sangat cepat bermunculan kampus-kampus baru lainnya. Apa yang kemudian terjadi? Memang diakui bahwa dengan adanya kampus mulia, dengan sendirinya terbangun pula jasa kos, foto copi, laundry, warung makan dan lain sebagainya. Diakui ada kampus-kampus baru yang lain tetapi tidak sebanyak yang diperkirakan.

Ada kampus yang tutup alias gulung-tikar, atau ganti nama atau ganti program studi. Ada pula kampus baru yang sesungguhnya lama, akan tetapi jumlah mahasiswanya banyak; ada kampus baru tetapi menggantikan dengan program studi baru sama sekali, dan gedungnya sebenarnya lama; ada kampus yang hampir mati dan lain sebagainya. Pada kenyataannya, dengan ada kampus mulia maka jumlah bangunan fisik pun terjadi, di samping berbagai isu kejahatan seperti kejahatan moral pemerkosaan dan perselingkuhan serta pacaran melampaui batas norma-norma, kejahatan ekonomi seperti pencurian, penggelapan dan lain sebagainya. Alat tranportasi pun dipersiapkan, katakanlah tranjogja, kopata dan angkutan desa bahkan belakangan muncul gojek dan grap dengan harga terjangkau. Jadi, hampir tidak kita temukan kampus yang sama sekali baru, baik milik pemerintah maupun milik swasta.

Kalau ada tesis yang menggambarkan suatu wilayah dengan dibangunkan kampus baru maka dengan sendirinya akan berkembang pula kampus-kampus yang lain, tidak sepenuhnya benar. Kampus baru lain 
sama sekali tidak terlihat untuk dibangun. Bahkan yang terjadi adalah disparitas antara penduduk setempat dengan penduduk pendatang. Kita tidak tahu persis, apa yang bakal terjadi untuk 100 tahun ke depan. Masa kini, penduduk sama sekali tidak berbaur, sebagaimana yang kita lihat dalam kerja bakti maupun gotong-royong, sedekah kampung dan peristiwa 17-an. Mereka yang merayakan adalah penduduk setempat, sementara ditinggal oleh penduduk pendatang dengan mendengkur. Demikian pula dengan ronda kampung, tidak terjadi sama sekali untuk penduduk pendatang meski mereka diwajibkan untuk menyediakan uang ronda (dulu ronda dengan beras, satu jumput).

Penduduk setempat entah menyadari atau tidak, bahwa semua itu butuh kebersamaan. Tetapi, penduduk pendatang dibiarkan saja berlalu dan seolah-olah dianakemaskan. Kecuali mereka yang bekerja mungkin ada toleransinya. Pos rondanya pun sudah ganti lokasi beberapa kali. Kita tidak tahu maksud dari pergantian itu. Isu-isu yang terdengar disebabkan pemilik tanah menghendaki tanahnya dikembalikan karena berrdiri di atas lahan miliknya dan mau dipergunakan. Memang pada kenyataan, pos ronda dibangun di atas tanah milik seseorang dengan tanpa pemberitahuan terlebih dahulu. Mereka mengira bahwa dengan jumlah orang yang cukup banyak maka dengan sendirinya pemilik tanah tidak dapat berbuat apa-apa, seperti yang dikatakan Durkhiem dengan konsep solidaritas dan keseimbangan.

Mungkin yang menarik untuk disimak, bahwa dengan dibangunnya pos ronda diharapkan pencurian tidak terjadi, padahal pencurian masih tetap ada. Belum lama ini, bahkan seorang tukang kayu sampai kehilangan alat pertukangan di malam hari sehingga keesokan harinya tukang kayu tersebut tidak dapat bekerja. Jadi, pos ronda hanya dipergunakan penduduk yang banyak tadi, tanpa mampu mempertanggung jawabkan perilaku mereka andaikan ada pencuri masuk ke wilayah mereka. Pos ronda nampaknya hanya formalitas belaka.

Pencurian tanah pun masih kerap terjadi, pergeseran patok tanah, pergantian tanah yang tidak sesuai, dan pemakaian jalan setapak serta gang/lorong untuk penduduk dan lain sebagainya; pada penduduk setempat masih terus berlangsung di antara mereka. Hampir dipastikan bahwa hak kepemilikan adalah milik pribadi penduduk setempat. Bukan berarti 
mereka tidak mengetahui tentang hukum pertanahan misalnya. Melainkan karena kekuatan fisik, menggunakan sarana kolektif meski mungkin justru mereka sendiri yang berbuat tidak benar, keegoisan, keserakahan, banyak bicara merupakan sarana paling efektif untuk menekan kelompok yang lebih sedikit orang. Sementara, pemilik tanah tidak ingin ribut-ribut, bukankah sebaiknya memiliki tanah yang lain yang diizinkan, atau mendiamkan saja jika dilihat dari perspektif agama. Maksudnya, jika ada kelompok masyarakat berusaha memiliki tanah yang bukan haknya hubungannya diakhirat kelak.

Dalam batasan tertentu, memang agama menjadi faktor dominan terutama hubungan dengan kesediaan untuk menyisihkan sebagian dana, padahal untuk kehidupan keluarga pun sudah tidak mencukupi. Demikian pula jika ada orang yang meninggal dunia maka dengan sangat ringan dalam menyisih sebagian hartanya. Namun untuk hal-hal yang bersifat kurang produktif seperti rekreasi misalnya, akan sangat sulit ke luar dari sakunya. Dua hal yang tidak sama, dilakukan orang yang sama. Pernah suatu ketika penulis memergoki sebuah amplop di antara amplop berisi uang yang lain tetapi untuk sebuah amplop itu hanya berisi sabun deterjen. Terpenting sudah menyumbang.

Hubungan dengan sesama, juga unik. Sama sekali tidak disinggung tentang penduduk pendatang. Setiap ada pekerjaan desa seperti yang dikemukakan di atas, penduduk pendatang sama sekali tidak dilibatkan kecuali ada penduduk pendatang yang menyediakan diri untuk bergabung. Selebihnya, penduduk pendatang tadi akan dijadikan objek yang terus menerus dilibatkan termasuk halhal yang kurang pantas diterima oleh nilai-nilai dan norma-norma masyarakat. Katakanlah, sebagai peminta uang dari rumah ke rumah penduduk untuk kegiatan desa, atau ada yang meninggal dan seterusnya. Sementara penduduk setempat, dalam pertemuan desa, jika ada yang berbuat melebihi kapasitasnya, langsung diejek dan diolok-olok usai pertemuan. Padahal yang dibicarakan untuk kepentingan penduduk setempat itu sendiri. Untuk urusan pengajian, yang baca atau hafalan adalah tahlilan dan yang itu-itu saja. Jadi bukan Al-Quran sebagai kitab suci yang ditelaah.

Hal yang paling menjengkelkan, ada sekelompok orang untuk tidak mengajak bekerja-bersama penduduk setempat, yang menjadi sasaran/objek, meskipun orang yang bersangkutan 
berada di samping orang lain yang mau diajak. Sekelompok orang tadi dapat seenaknya mengatakan sesuatu yang kurang baik terhadap penduduk setempat itu, bahkan jika ada penduduk setempat yang lain mencoba untuk menyelamatkan penduduk setempat tadi, maka tidak ada keberanian untuk melakukan itu. Tahunya hanya diam belaka. Atau turut menyalahkan penduduk setempat tadi, padahal yang bersangkutan tidak mengerti apa-apa. Demikian pula jika ada orang tua/sepuh usianya, juga tidak dianggap. Bahkan orangtua itu pun malah terjadi, ketakutan sama sekali.

Sepertinya tidak ada perubahan perilaku yang signifikan dari sebagian penduduk setempat. Sikap-sikap demikian dari tahun ke tahun makin menguat dan makin mengeras. Kecuali jika ada orangtua terutama ibu-ibu agak berbeda perilaku penduduk. Dengan didampingi ibu-ibu maka semua itu tidak akan terjadi seperti perlakuan mereka terhadap orangtua laki-laki. Mungkin sekelompok orang tadi terlihat sungkan jika bertengkar dengan ibu-ibu sekampung. Artinya, dengan kehadiran kampus mulia di wilayah mereka bukan adaptasi yang ditempuh tetapi pengerasan perilaku yang terjadi. Bagi penduduk setempat lain, tidak sebagaimana terjadi seperti sekelompok penduduk setempat itu berbeda, terutama yang memiliki tanah luas dan dibangun kamar-kamar kos.

Mereka mengganggap anak kos sebagai asset (mendatangkan uang) bagi keluarga. Tetapi karena ketakutan atas sekelompok penduduk setempatlah maka sikap dan perilaku mereka diam atau bersungut-sungut saja yang seolah-olah menyetujui tindakan sekelompok penduduk setempat. Mungkin hal demikian dapat terjadi mengingat tingkat pendidikan formal penduduk setempat tidak terlalu tinggi. Paling tinggi hanya menamatkan pendidik di tingkat SMA/Kejuruan, selebihnya hanya menamatkan SMP dan mungkin SD. Sementara dari sisi pekerjaan orangtua, kebanyakan tukang kayu dan tukang batu untuk mendirikan rumah orang lain.

\section{Bentuk-Bentuk Perlawanan Petani.}

Hampir sebagian besar penduduk setempat tersebut adalah petani. Terlepas, apakah petani yang memiliki tanah milik sendiri, memburuh pada orang lain maupun warisan dari orangtua. Sebagai besar sebagai petani sudah merupakan jalan hidup mereka (way of life). Demikianlah hidup tanpa perlu diubah dan kita pasrah saja kepada Tuhan Yang 
Maha Esa, toh gusti Allah yang ngatur. Begitulah kira-kira yang dapat disimpulkan dari sikap dan perilaku petani di wilayah tersebut. Ada kepasrahan, ketertutupan, isu-isu yang berkembang seputar pertanian mereka. Memang ada satu-dua dari anak-anak petani yang merantau ke luar desa tetapi kebanyakan dari mereka yang kembali (ada yang belum kembali saat tulisan ini dibuat) bukannya membangun desanya tetapi justru bersikap bertentangan dengan desanya, sehingga desanya semakin tertinggal.

Dengan berdirinya kampus mulia di wilayah mereka, dapat diartikan sebagai anugerah bagi masyarakat tertentu dan ada pula yang menganggap celaka terutama bagi mereka yang tidak siap maupun pasrah begitu saja (Stompka, 2011). Dengan kehadiran kampus mulia itu sangat sedikit atau mungkin tidak ada perubahan sama sekali dari mereka yang memiliki tanah yang besarannya sedangsedang saja. Katakanlah sekitar 1-2 ha. Mereka hanya memiliki kurang dari 1 ha dan beberapa gelintir saja yang lebih dari 2 ha. Sedang aparat desa saja kurang dari 1 ha. Atau kalau lebih pun tempatnya berserakkan di tempat-tempat lain. Bukan pada satu lokasi. Sebagai tambahan mereka penduduk setempat ada yang sebagian kecil sebagai tukang becak dan tukang kayu serta tukang batu. Kalau pun mereka PNS hanya kelompok bawahan di instansi masing-masing. Pasalnya, mereka hanya sampai berpendidikan Sekolah Menengah Atas/khusus atau kejuruan. Bahkan tidak jarang dari mereka hanya menamatkan pendidikan Sekolah Dasar (SD). Wajar jika mereka ditempatkan sebagai penjaga malam atau menyediakan air minum bagi staf dan pimpinan.

Memang, menjadi PNS menjadi dambaan anak petani tersebut. Meski mungkin hanya sebagai pesuruh. Tetapi gaji bulanan sudah cukup bagi mereka. Kalau melihat dari perubahan-perubahan yang terjadi, sesungguhnya hanya perubahan horizontal saja. Sementara yang vertikal hanya isapan jempol belaka. Mana mungkin anak-anak petani yang paling tinggi hanya menamatkan pendidikan di SLTA akan mendapat pekerjaan yang lebih baik? Bahkan, yang kita lihat kebanyakan tamat SMP dan SD saja. Mengenai ganti rugi tanah yang diambil untuk pendirian kampus mulia itu, kalau sekarang, sudah tidak cukup signifikan besarnya. Terbukti, tidak ada satu pun di antara petani yang mendapatkan ganti-rugi dapat membangun rumah yang baru dan layak 
huni, memiliki kendaraan roda empat, atau menyekolahkan anak lebih tinggi dari yang hanya menamatkan pendidikan SLTA. Tidak ada itu. Tetapi bagi mereka yang menmatkan pendidikan SLTA dan bekerja di kampus mulia dengan biaya sendiri melanjutkan ke jenjang yang paling tinggi. Pertanyaannya, apakah ganti-rugi yang diberikan kurang besar atau pikiran petani yang kurang terbuka.

Dari mereka yang kehilangan sawah, sebagian mereka menjadi pembantu di kampus mulia tanpa menjadi PNS karena faktor usia. Memang, mereka mendapat prioritas kalau ada rekrutmen pagawai, Alasannya karena dahulu kampus mulia berdiri di atas tanah mereka. Tetapi, seperti yang sudah disebutkan, hanya sebagai pekerja bawahan belaka. Itupun harus diketahui, dilakukan pimpinan di kampus mulia itu saja. Sekarang, pergantian pimpinan sudah $3 \mathrm{kali}$, dari yang pertama. Pimpinan yang kedua dan ketiga ini tidak memiliki beban sama sekali, karena tidak terjun langsung saat mereka (anak petani) diterima kerja.

Pimpinan yang sekarang, tidak terlalu perduli dengan petani setempat atau penduduk setempat. Padahal dahulu, dia juga ikut membantu pendirian dan melakukan negosiasi dengan petani setempat dalam rangka untuk mendirikan kampus mulia. Tetapi mungkin urusan dengan petani setempat dianggap sudah berakhir dengan ditanda tangani kesepakatan, maka semua itu sudah selesai. Jika pimpinan pertama, masih menghargai dan menghormati petani setempat, katakanlah ada dies maupun wisuda dan lain-lain; hampir dipastikan petani setempat diajak serta untuk menghadiri kegiatan yang diselenggarakan kampus mulia. Duduknya pun di depan bersama-sama dengan pejabat pemerintah lainnya. Kecuali hulu jika mantan dukuh dan aparat desa lainnya untuk mendapatkan pekerjaan di kampus mulia. Itupun sudah tidak lagi dilakukan oleh petani biasa, terutama aparat desa. Sekarang, petani pada umumnya sudah tidak diperlakukan sama baiknya oleh pimpinan kampus mulia dan bahkan karyawannya.

Pada perkembangannya, kalau ingin bekerja di kampus mulia, silakan berkompetisi sama dengan yang lain, tanpa perlu katebelece dari pimpinan. Itulah sebabnya, pekerjaan di sektor formal sudah tidak lagi mereka dapatkan, kini, petani bergerak di sektor informal bersama dengan orang lain yang mencari usaha di kampus mulia. Dari sebagian petani terutama mereka yang sawahnya sudah dipergunakan kampus mulia ada 
yang menjual makanan basah, ada yang menjual soto dan burjo, ada yang menjual pulsa di sekitar kampus, ada yang menjual mie ayam, jasa foto copi, kos serta penjilidan dan lain sebagainya.

Bagaimana kemudian bentukbentuk perlawanan petani sisanya di wilayah itu? Barangkali harus kita petakan dahulu kampus mulia itu ada di mana? Kampus mulia itu berdiri di atas lahan (dahulu bekas sawah petani dan tempat pemakaman tahanan G $30 \mathrm{~S}$ PKI yang ditembak mati) seluas lebih dari 50 ha. Dahulu semak belukar dan sawah yang berdiri di pinggiran kota. Secara administratif untuk memudahkan aparat kecamatan ke kota Yogyakarta, dibangun jalan yang cukup baik dan diberi fasilitas layaknya sebuah kota. Padahal dia adalah sebuah kecamatan salah satu kabupaten. Secara sosiologis, dia berada di zombie area (Daerah Hantu). Disebut demikian, wajar mengingat perilaku menyimpang sering terjadi di wilayah ini. Katakah geng motor, penyiletan tas perempuan, penculikan, orang yang sedang berpacaran dan asusila lain, lokalisasi, orang yang berjalan sendirian dan lain sebagainya. Artinya, tempat transisi di mana sinyal telepon seluler pun agak tersendat-sendat dan juga mungkin hilang.
Dengan kondisi seperti ini, kelihatannya tidak sefrontal petani di Asia Tenggara (Scott) melakukan perlawanan langsung. Agaknya, langkah demikian tidak dilakukan dan Scott sendiri tidak mempertimbangkan banyak hal. Seperti luas lahan yang di pajak, kedekatan dengan kota, bentuk pemerintahan, adanya jalur transpotasi dan lain sebagainya. Dengan dibangun kampus mulia, mudah dijangkau, baik mahasiswa Yogyakarta sendiri maupun pendatang atau kalau mereka mau kos di wilayah tersebut. Harga tanah sudah melambung tinggi dan cepat sekali perubahannya. Pada saat kampus mulia berdiri, harga tanah masih berkisar rp 25.000 per meter, dewasa ini sudah menembus angka rp 1.500 .000 per meter. Memang ada sebagian kecil yang memanfaatkan dan menikmati kenaikan harga tersebut sehingga petani dapat membeli dengan harga yang rendah dari petani lain, tetapi lebih dari separoh petani tidak menyadari itu atau mereka terlalu asyik dengan petaninya tidak tahu perkembangan.

\section{Kesimpulan}

Dengan kehadiran kampus mulia di DIY seharusnya banyak terjadi perubahan (sosial), yang sudah lebih dari 35 tahun itu. Tetapi perubahan- 
perubahan tidak terlalu cepat. Mungkin karena tempatnya dibangun di daerah pinggiran kota sehingga para mahasiswa enggan kuliah ke sana, atau karena prodinya khusus. Padahal harapan pemerintah bahwa fungsi kampus dapat dipergunakan sebagai "pemicu" mekarnya kota. Tetapi hubungan dengan perkembangan kota relatif tidak terjadi. Memang diakui bahwa telah terjadi banyak perubahan tetapi perubahan yang relatif hanya secara fisik belaka; di mana sebagiannya berbentuk rumah kos, foto copi, warung-warung makan, pembantu rumah tangga, internet dan lain sebagainya; yang dilakukan penduduk setempat. Sudah lebih dari tiga dasawarwa dengan kehadiran kampus mulia di wilayah mereka, tranformasi sosial tidak berlangsung baik, bahkan pengerasan-pengerasan yang ditunjukkan oleh sebagian penduduk setempat.

Pendidikan, yang diharapkan tidak berjalan efektif dan sekarang justru mendapatkan serangan narkoba serta kejahatan seksual yang dilakukan oleh penduduk setempat sendiri. Penduduk pendatang yang kebanyakan terdiri dari mahasiswa hanya sebagai penonton belaka. Sementara bentuk-bentuk perlawanan petaninya pun relatif tidak seperti yang digambarkan Scott di
Vietnam dan Burma. Bisa jadi berbeda memang seperti pangambilan pajak yang secara sporadis tidak terjadi atau dicap sebagai penganut partai terlarang juga tidak terjadi. Ada kesan bahwa semua adem-ayem saja. Ganti rugi sudah diberikan dan dengan kehadiran kampus mulia telah dapat menaikan tingkat pendapatan juga petaninya bersikap sangat akomodatif. Sarana pelengkap penduduk setempat yang menyediakan seperti rumah kos, rumuah makan, foto copy, salon, internet, laundry dan lain lain. Memang bagi penduduk setempat yang kurang mendukung atas dibangunnya kampus mulia di wilayah mereka tentu ada yang pindah tempat, ganti profesi dan lain sebagainya, tetapi petani ini masuk dalam kelompok kecil saja sehingga tidak mengganggu jalannya pendirian kampus mulia.

\section{DAFTAR PUSTAKA}

Lenner, Daniel. 1983. Memudarnya Masyarakat Tradisional. GUP. Yogyakarta

Kartodirdjo, $\quad$ Sartono. 1984. Pemberontakan Petani Banten 1884. PT Dunia Pustaka Jaya. Jakarta

Kuntowijoyo. 1993. Radikalisme Petani. Bentang. Yogyakarta 
Scott, C, James. 1983. Moral Ekonomi Petani. LP3ES. Jakarta

1993. Perlawanan

Kaum Tani. Obor. Jakarta
Stompka, Piotr. 2011. Sosiologi Perubahan Sosial. Prenada. Jakarta 